\title{
STUDY OF POTENTIAL TOXICITY OF ZINC AND ITS OXIDE NANOPARTICLES ON BLOOD PARAMETERS, MORPHOLOGICAL AND FUNCTIONAL STATE OF LIVER AND ELEMENT STATUS OF PREGNANT WISTAR RATS AND FETUS
}

\section{E.A. RUSAKOVA1, E.A. SIZOVA1, 2 , S.A. MIROSHNIKOV ${ }^{2}$, O.Yu. SIPAILOVA1, Sh.A. MAKAEV 2}

\begin{abstract}
${ }^{1}$ Orenburg State University, 13, prosp. Pobedy, Orenburg, 460018 Russia, e-mail elenka_rs@mail.ru, osipaylova@mail.ru;

${ }^{2}$ All-Russian Research Institute of Beef Cattle Breeding, Federal Agency of Scientific Organizations, 29, ul. 9 Yanvarya, Orenburg, 460000 Russia, e-mail sizova-178@ya.ru, vniims.or@mail.ru Acknowledgements:

Hematological studies were performed using standard techniques in the Laboratory of Agroecology of Nanomaterials and Test Center of All-Russian Research Institute of Beef Cattle Breeding (accreditation certificate RA. RU.21PF59 from 12/02/15). Analysis of chemical elements was performed in the laboratory of ANO Center for Biotic Medicine, Moscow (accreditation certificate GSEN.RU.TSAO.311, registration number in the State Register ROSS RU. 0001.513118).
\end{abstract}

Supported by Russian Scientific Foundation (project № 14-36-00023)

Received June 5, 2016

\section{Abstract}

Nanoparticles of zinc ( $\mathrm{Zn}$ NPs) and zinc oxide ( $\mathrm{ZnO}$ NPs) are considered as materials of low toxicity, as $\mathrm{Zn}$ is the most important trace element in human body usually found in food and used as a food additive. Currently, there is a serious lack of information about the potential dangers of nanomaterials (NMs) for mammals, and particularly for human. Moreover, there is not enough information about their potential hazard for reproductive health. The aim of this study is to investigate the potential negative effects of positively charged 90 and $95 \mathrm{~nm}$ nanoparticles of zinc (Zn NPs) and zinc oxide (ZnO NPs) on metabolic processes during pregnancy according to morphological and biochemical blood indices, morphofunctional structure of liver and element status in Wistar rats and fetuses. Blood was collected from 21-day old animals. Of blood morphological indices, concentration of erythrocytes $\left(10^{12} / 1\right)$, white blood cells $\left(10^{9} / 1\right)$, hemoglobin $(\mathrm{g} / \mathrm{l})$, hematocrit $(\%)$ was estimated. In blood serum ALT (U/l), AST (U/l) and LDH (U/l) activity was assessed. Tissue samples were analyzed on a mass spectrometer Elan 9000 and atomic emission spectrometer Optima $2000 \mathrm{~V}$ (Perkin Elmer, USA). We did not observe embryo-fetal pathology in rats in the experiment. The concentration of red blood cells and hemoglobin increased when Zn NPs injected. ZnO NPs application led to the development of mild leukocytosis. Increasing activity of enzymes (ALT, AST, LDH) demonstrates the destructive process in hepatocytes of mother rats, which depends directly on the dose and type of the nanoparticles. Generally, the blood parameters confirm a potentially hepatotoxic effect of Zn NPs and ZnO NPs which was shown histologically. Microstructural changes of liver tissue (degeneration and cytolysis along with regeneration and functional activation of the body) may be considered as compensatory (adaptive) response to the toxic effects of the nanoparticles. According to the severity of these phenomena and given comparable doses, the $\mathrm{ZnO}$ NPs can be attributed to more toxic NPs than Zn NPs. Zn NPs and ZnO NPs did not lead to critical changes in the pool of macro- and microelements and $\mathrm{Zn}$ level in liver of mother rats and fetal tissues. There was an accumulation of essential elements, though it had no notable influence on the course and outcome of pregnancy in the rats. The most expressed biological effect of nanoparticles was observed in the rats at the maximum doses of $\mathrm{Zn}$ NPs and $\mathrm{ZnO}$ NPs.

Keywords: rats, Zn NPs, ZnO NPs, blood, liver, pregnancy, fetus, chemical elements

Zinc $(\mathrm{Zn})$ and zinc oxide $(\mathrm{ZnO})$ nanoparticles (NPs) are among the most commonly used nanomaterial groups [1]. ZnO NPs are used in the manufacture of plastics, ceramics, glass, cement, rubber, lubricants, paints, ointments, adhesives, sealants, pigments, batteries, ferrites, antipyrenes, etc. [2]. Zn NPs and ZnO NPs are capable of UV shielding and have antibacterial and deodoriz- 
ing effects with a potential wide use in cosmetics and in the production of sunscreens [3], in the food industry as additives and in the composition of packages [4], as fungicides in agriculture [5], and as anticancer drugs [6, 7].

Since zinc belongs to essential trace elements, $\mathrm{Zn}$ nanoparticles are usually considered as low toxicity substances. However, there are reports on the development of metal fume fever which may follow inhalation of $\mathrm{ZnO}$ vapor $[8,9]$. At the same time, it is difficult to predict the effects of the contacts with zinc nanoparticles as nanomaterials exhibit high reactivity [10), are well dispersible in various media [11], and their uptake by living systems can occur by various mechanisms [12].

Currently, there is a serious lack of information about the potential dangers of nanomaterials (NMs) for human health, and particularly about the potential effects on the endocrine and reproductive systems. There is evidence suggesting that NP effects may interfere with the regulation of blood sex hormone concentration. Some nanomaterials cause endocrine dysfunction [13]. Fetotoxic effects of nanosilica $(70 \mathrm{~nm})$ have been found; these effects are manifested in fetal resorption or limitation of fetal growth and development [15].

We were the first to demonstrate that 90 and $95 \mathrm{~nm}$ positively charged $\mathrm{Zn}$ and $\mathrm{ZnO}$ nanoparticles have an impact on the overall pool of macro and microelements and $\mathrm{Zn}$ levels in the liver of rats and fetal tissues. Blood chemistry studies have found a potential hepatotoxic effect of these nanoparticles. At this, microstructural reorganization of the liver reflected degeneration and cytolysis processes. At the same time, compensatory reactions providing regeneration and organ function recovery took place.

The purpose of this study was to investigate the potential negative effects of $\mathrm{Zn}$ and $\mathrm{ZnO}$ nanoparticles on hematological parameters, morphofunctional structure of the liver and the level of essential elements in laboratory rats during pregnancy.

Ttechnique. The experiments were performed in accordance with the protocols of the Geneva Convention and the principles of Good Laboratory Practice (Russian Federation National Standard GOST R 53434-2009) [16] and with the instructions recommended by The Guide for the Care and Use of Laboratory Animals (National Academy Press Washington, DC, 1996). Animal care was carried out according to the Good Laboratory Practice in conducting preclinical research in the Russian Federation (GOST 51000.4-96 3) [17]. The experiments were conducted in compliance with the requirements of humane treatment of animals [18]. Standard operating procedures for biological objects were used in the experiment.

$\mathrm{Zn} \mathrm{NPs}$ of $90.0 \pm 2.0$ and $95.0 \pm 2.0 \mathrm{~nm}$ and $\mathrm{ZnO}$ NPs of 5.34 and 4.5$6.0 \mathrm{~m}^{2} / \mathrm{g}$ specific surface were used. Nanoparticles were produced by "Peredovye poroshkovye tekhnologii" (Tomsk) and Platina LLC (Moscow) using electric explosion of wire in argon atmosphere. Composition of Zn NPs: Zn - $90 \%$, sorbed gases, $\mathrm{ZnO}$, and $\mathrm{H}_{2} \mathrm{O}$. Composition of $\mathrm{ZnO}$ NPs defined by plasma chemical method: $\mathrm{ZnO}-96 \%$, other metal oxides $-4 \%$. $\mathrm{Zn} \mathrm{NP}$ and $\mathrm{ZnO}$ NP for intraperitoneal administration were prepared in isotonic saline by $30 \mathrm{~min}$ processing in ultrasonic disperser UZDN-2T (SPE Akadempribor, Russia) (5 $\mathrm{kHz}, 300 \mathrm{~W}, 10 \mathrm{uA})$.

Studies were performed with Wistar rats under the conditions of biomedical clinic (Orenburg State University vivarium). Male and female rats aged 10 weeks were kept at a temperature of $20.8-23.0{ }^{\circ} \mathrm{C}$, relative humidity of 45-57\%, artificial lighting for 12 hours and 10-15-fold air exchange. For mating, the equal numbers of males and females were collected. Pregnancy was defined by the presence of vaginal plugs and sperm in a smear with daily 
studies. Pregnant rats were placed into a cage with stainless steel wire lids. Water and feed (normal diet) were provided ad libitum.

Healthy 3 months old pregnant females with body weights of 250-300 g $(n=60)$ were randomized into six groups (control group and five experimental groups). Group I rats were inoculated with Zn NPs $(1.4 \mathrm{mg}$ per $1 \mathrm{~kg}$ of live weight); group II rats - with Zn NPs $(2.8 \mathrm{mg} / \mathrm{kg})$; group III rats - with $\mathrm{Zn}$ NPs $(7.1 \mathrm{mg} / \mathrm{kg})$; group IV rats - with ZnO NPs $(1.4 \mathrm{mg} / \mathrm{kg})$, and group V with $\mathrm{ZnO}$ NPs $(8.9 \mathrm{mg} / \mathrm{kg}$ ). Nanoparticles (or $0.2 \mathrm{ml}$ saline in the control) were administered in females in early pregnancy (immediately after diagnosis) once intraperitoneally in compliance with the rules of aseptics and antiseptics. During pregnancy, the animals were examined daily for clinical signs (mortality, overall appearance, and behavior). At the end of the experiment (day 21), rats were decapitated under nembutal anesthesia.

Erythrocyte count $\left(\times 10^{12} / \mathrm{l}\right)$, leukocyte count $\left(\times 10^{9} / \mathrm{l}\right), \mathrm{Hb}(\mathrm{g} / \mathrm{l})$ and hematocrit $(\%)$ were measured using an automated hematology analyzer URIT2900 Vet Plus (URIT Medical Electronic Group Co., Ltd, China), alanine aminotransferase (ALT), aspartate aminotransferase (AST) and lactate dehydrogenase (LDH) activity (U/l) was determined by an automatic biochemical analyzer CS-T240 (DIRUI Industrial Co., Ltd, China) using commercial biochemical kits DiaVetTest for veterinary (Russia).

For morphological studies, pieces of liver tissue were fixed in $10 \%$ neutral formalin and embedded in paraffin mixture HISTOMIX ${ }^{\circledR}$ (BioVitrum LLC, Russia). The 5-6 $\mu \mathrm{m}$ thick histological sections were prepared using a semiautomatic microtome (01 MW, Tekhnom, Russia), stained with hematoxylin and eosin and examined under a light microscope MT 5300L (Meiji Techno Co., Ltd, Japan, ×400).

The content of chemical elements in the tissue samples studied was measured using a mass spectrometer Elan 9000 and atomic emission spectrometer Optima 2000V (Perkin Elmer, USA).

Statistical analysis compared the data from the experimental groups with the control using SPSS 19.0 (IBM Corporation, USA) and 10 Statistica (StatSoft Inc., USA) software. The $\mathrm{p} \leq 0.05$ level was considered statistically significant. The mother's body weight parameters were subjected to analysis of variance (ANOVA) and multiple comparison Scheffe test which was used when the differences were significant [19].

Results. Hematological parameters and morphological changes in the rat liver. We have found a significant increase in erythrocyte counts in the groups inoculated with Zn NPs at a dose of 2.8 and $7.1 \mathrm{mg} / \mathrm{kg}$. By the end of the experiment, in the animals of froups II and III, this parameter exceed the reference values by 17.40 and $11.30 \%$, respectively $(\mathrm{p} \leq 0.05)$ (Table 1$)$.

1. Hematological parameters in pregnant Wistar rats at day 21 after intraperitoneal administration of $\mathrm{Zn}$ and $\mathrm{ZnO}$ nanoparticles (NPs) at various doses $(X \pm x)$

\begin{tabular}{|c|c|c|c|c|c|c|}
\hline \multirow{2}{*}{ Parameter } & \multicolumn{6}{|c|}{ Group } \\
\hline & control & I & II & III & IV & $\mathrm{V}$ \\
\hline Leucocytes, $\times 10^{9} / 1$ & $8.23 \pm 0.24$ & $7.63 \pm 0.22$ & $7.97 \pm 0.69$ & $6.03 \pm 0.23^{*}$ & $14.40 \pm 0.50$ & $9.67 \pm 0.23^{* *}$ \\
\hline Erythrocytes, $\times 10^{12} / 1$ & $7.55 \pm 0.25$ & $7.98 \pm 0.27$ & $8.86 \pm 0.23^{*}$ & $8.40 \pm 0.26^{*}$ & $8.12 \pm 0.09$ & $7.73 \pm 0.13$ \\
\hline Hemoglobin, g/l & $156.70 \pm 7.17$ & $164.30 \pm 6.19^{*}$ & $187.70 \pm 6.67^{*}$ & $171.70 \pm 11.20$ & $166.30 \pm 3.45$ & $158.70 \pm 5.96$ \\
\hline Hematocrit, $\%$ & $40.30 \pm 1.82$ & $41.60 \pm 4.13$ & $47.90 \pm 1.44^{*}$ & $45.00 \pm 2.41$ & $43.60 \pm 0.72$ & $40.80 \pm 1.88^{*}$ \\
\hline $\begin{array}{l}\mathrm{N} \text { o t e. Group I - } \\
\mathrm{IV}-1.4 \mathrm{mg} / \mathrm{kg} \mathrm{Zn} \\
{ }^{*},{ }^{* *} \text { Differences wit }\end{array}$ & $\begin{array}{l}\text { mg/ } \mathrm{kg} \mathrm{Zn} \\
\text { vPs, group V } \\
\text { he control ar }\end{array}$ & $\begin{array}{l}\text { Ps, group II } \\
-8.9 \mathrm{mg} / \mathrm{kg} \mathrm{Z} \\
\text { statistically sis }\end{array}$ & $\begin{array}{l}2.8 \mathrm{mg} / \mathrm{kg} \mathrm{Zn} \\
\text { NPs. }\end{array}$ & NPs, group I & $-7.1 \mathrm{mg} / \mathrm{kg}$ & Zn NPs, group \\
\hline
\end{tabular}

A statistically significant increase in hemoglobin levels was observed in groups I and II, by 4.85 and $19.80 \%$, respectively $(\mathrm{p} \leq 0.05)$ versus the control group (see Table 1). 
Leukocyte counts in the blood of group IV and $\mathrm{V}$ animals were by 74.90 and $17.00 \%$ greater, respectively $(\mathrm{p} \leq 0.01)$ compared to control. $\mathrm{Zn}$ NPs at a dose of $7.1 \mathrm{mg} / \mathrm{kg}$ caused significant changes in leukocyte counts (see Table 1). The similar effect of nanoparticles upon intraperitoneal administration has been described previously [20].

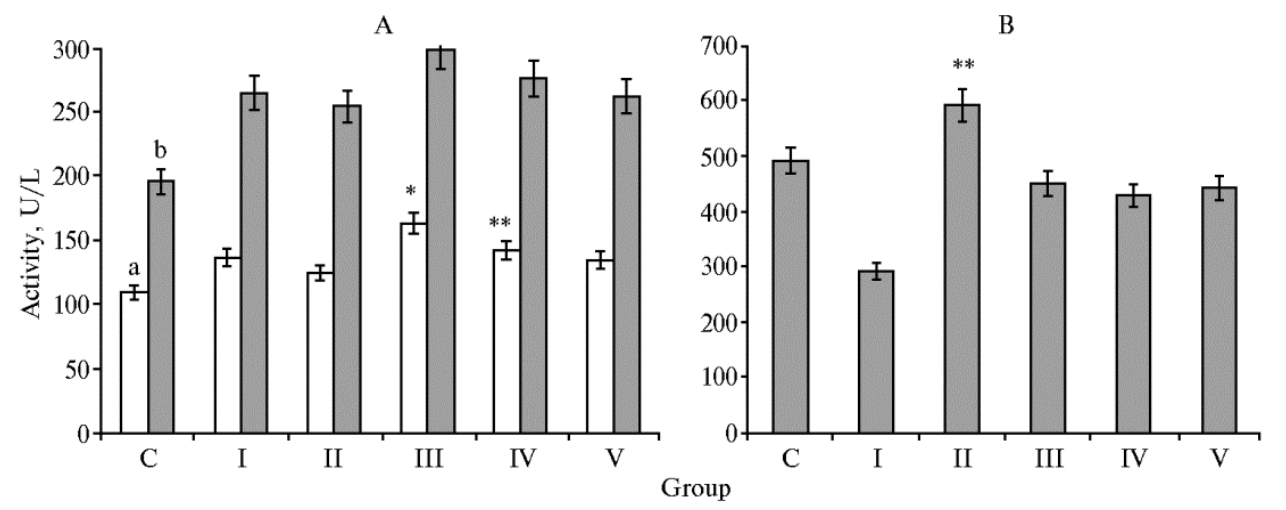

Blood aminotransferases (A) and lactate dehydrogenase (B) activity in pregnant Wistar rats at day 21 after intraperitoneal administration of $\mathrm{Zn}$ and $\mathrm{ZnO}$ nanoparticles (NPs) at various doses: a - alanine aminotransferase, b - aspartate aminotransferase; group I $-1.4 \mathrm{mg} / \mathrm{kg} \mathrm{Zn} \mathrm{NPs,} \mathrm{group} \mathrm{II} \mathrm{-}$ $2.8 \mathrm{mg} / \mathrm{kg} \mathrm{Zn} \mathrm{NPs,} \mathrm{group} \mathrm{III} \mathrm{-} 7.1 \mathrm{mg} / \mathrm{kg} \mathrm{Zn} \mathrm{NPs,} \mathrm{group} \mathrm{IV}-1.4 \mathrm{mg} / \mathrm{kg} \mathrm{ZnO} \mathrm{NPs,} \mathrm{group} \mathrm{V} \mathrm{-}$ $8.9 \mathrm{mg} / \mathrm{kg} \mathrm{ZnO}$ NPs; C - control.

*, ** Differences with the control are statistically significant with $\mathrm{p} \leq 0.05$ and $\mathrm{p} \leq 0.01$, respectively.

Injections of $\mathrm{Zn}$ and $\mathrm{ZnO}$ NPs altered homeostatic blood parameters contributing to an increase in transaminases (ALT, AST) and LDH activity. At day 21, ALT values in groups III and IV were significantly higher compared to control by $48.60 \%(\mathrm{p} \leq 0.05)$ and $29,60 \%$ ( $\mathrm{p} \leq 0.01)$, respectively. With dosing $1.4 \mathrm{mg} / \mathrm{kg} \mathrm{ZnO} \mathrm{NPs} \mathrm{(group} \mathrm{IV),} \mathrm{blood} \mathrm{AST} \mathrm{activity} \mathrm{was} \mathrm{significantly} \mathrm{in-}$ creased by $40.80 \%(\mathrm{p} \leq 0.01)$, and at a dose of $8.9 \mathrm{mg} / \mathrm{kg}$ (group V) it increased by $33.80 \%(\mathrm{p} \leq 0.001)$ (Fig., A).

This was due to the massive release of enzymes into the bloodstream with cell destruction caused by various pathological processes. Increased ALT and AST activity in the blood plasma is considered one of the markers of liver disorders and is regarded as a reliable sign of its parenchyma lesions, since this parameter is in the direct proportion to the degree of liver involvement in the pathological process [21]. Analysis of serum lactate dehydrogenase activity demonstrated a statistically significant difference versus control (by $20.68 \%, \mathrm{p} \leq 0.01$ ) when $\mathrm{Zn}$ NPs were administered at a moderate dosage $(2.8 \mathrm{mg} / \mathrm{kg})$ (see Fig., B). Increased $\mathrm{Zn}$ NP doses and administration of comparable $\mathrm{ZnO}$ doses resulted in reduced $\mathrm{LDH}$ values, while the difference with control ranged from 8.09 to $12.64 \%$.

The diseases associated with tissue necrosis (myocardial infarction, necrotic kidney damage, hepatitis, pancreatitis) are known to be usually followed with a sharp increase in blood LDH activity [22], so it is possible to assume that such changes in the level of LDH are associated with the destruction of a limited cell population.

Analysis of enzyme activity (ALT, AST, LDH) reflecting the functional state of the liver, was consistent with the data on the assessment of its microstructural reorganization when exposed to nanoparticles. The intensity of such reorganization was directly dependent on the dose and type of nanoparticles. Thus, in rats administered with Zn NPs, the implications of degenerative changes of hepatocytes in the central parts of the lobes (as beam lobule structure recovery) and residual degenerative events in small lobular areas were observed. 
The number of hepatocytes with multiple nucleoli, polyploid and hyperchromatic nuclei increased, as well as the activity of Kupffer cells. Focal areas with the signs of necrosis and extensive zones with granular, atomized and vacuolar hepatocyte dystrophy were found only when $\mathrm{ZnO}$ NPs were administered. Increasing $\mathrm{Zn}$ NP doses to $8.9 \mathrm{mg} / \mathrm{kg}$ deepened necro-degenerative processes in the liver locally, on the one hand, and on the other hand, resulted in an increase in the areas of the islets of active proliferation of hepatocytes with larger, often polyploid nuclei, indicating activation of tissue regeneration.

In general, microstructural reorganization of the liver at day 21 after intraperitoneal injection of zinc nanoparticles in which there were cytolysis and degenerative changes, on the one hand, and regeneration and functional activation, on the other hand, may be considered as compensatory (adaptive) reactions with hepatotoxic effects of the nanoparticles used. According to the severity of these events and considering the comparable doses, ZnO NPs can be attributed to the most toxic ones compared to Zn NPs.

The early development of liver and lung tissue abnormalities is described under inhalative administration of ZnO NPs in rats at a dose of $2.5 \mathrm{mg} / \mathrm{kg} \mathrm{[23].}$ Probably, ZnO NPs can cause disorders in the energy metabolism, mitochondria and cell membranes in the rat kidney [24].

The issue of NP natural transition from the mother to the fetus is still poorly understood [25]. At the same time, publications describe some of the embryolethal effects of nanomaterials [26]. There is evidence of metal nanoparticle penetration to the liver and spleen of embryos from the mother's body [27].

We found no effects of Zn NPs and ZnO NPs on the course of pregnancy. Embryonic mortality and the ratio of live and dead fetuses were not different in the experiment and control, and there were no underdeveloped embryos and fetuses with external malformations in none of the groups. There were no statistically significant differences in the number and weight of fetuses between the groups and the control. These findings disagree with the results obtained by H. Zhang et al. [28] who stated a reduction in the reproductive qualities in rats under the effect of $\mathrm{ZnO}$ NPs.

2. Levels of chemical elements $(\mu \mathrm{g} / \mathrm{g})$ in the liver of Wistar mother rats and and fetus at day 21 after intraperitoneal administration of $\mathrm{Zn}$ and $\mathrm{ZnO}$ NPs at various doses $(X \pm x)$

\begin{tabular}{|c|c|c|c|c|c|c|}
\hline Sample & $\mathrm{Zn}$ & $\mathrm{Cu}$ & $\mathrm{Se}$ & $\mathrm{I}$ & $\mathrm{Fe}$ & $\mathrm{Ca}$ \\
\hline \multicolumn{7}{|c|}{ Control } \\
\hline Liver & $24.20 \pm 0.97$ & $3.99 \pm 0.07$ & $0.73 \pm 0.05$ & $0.11 \pm 0.02$ & $230.7 \pm 46.2$ & $37.60 \pm 1.21$ \\
\hline Fetus & $16.70 \pm 2.07$ & $4.64 \pm 0.09$ & $0.26 \pm 0.01$ & $0.02 \pm 0.01$ & $108.3 \pm 18.7$ & $441.40 \pm 4.83$ \\
\hline \multicolumn{7}{|c|}{ G ro u p I $\quad(1.4 \mathrm{mg} / \mathrm{kg} \mathrm{Zn}$ NPs $)$} \\
\hline Liver & $25.80 \pm 2.01$ & $3.84 \pm 0.17$ & $0.48 \pm 0.02$ & $0.11 \pm 0.02$ & $105.5 \pm 14.8$ & $35.50 \pm 1.48$ \\
\hline Fetus & $14.90 \pm 1.78$ & $1.72 \pm 0.15$ & $0.16 \pm 0.01$ & $0.07 \pm 0.17$ & $80.5 \pm 42.1$ & $404.30 \pm 19.40$ \\
\hline \multicolumn{7}{|c|}{ G ro u p II $(2.8 \mathrm{mg} / \mathrm{kg} \mathrm{Zn} \mathrm{NPs})$} \\
\hline Liver & $27.40 \pm 1.13$ & $4.01 \pm 0.06$ & $0.62 \pm 0.01$ & $0.11 \pm 0.07$ & $207.9 \pm 21.7$ & $41.00 \pm 2.09$ \\
\hline Fetus & $15.80 \pm 1.80$ & $2.46 \pm 0.13$ & $0.18 \pm 0.06$ & $0.05 \pm 0.03$ & $99.1 \pm 31.4$ & $417.70 \pm 22.10$ \\
\hline \multicolumn{7}{|c|}{ G ro u p III (7.1mg/kg Zn NPs) } \\
\hline Liver & $30.60 \pm 1.09$ & $4.78 \pm 0.10$ & $0.91 \pm 0.02$ & $0.12 \pm 0.05$ & $280.0 \pm 32.3$ & $50.40 \pm 4.04$ \\
\hline Fetus & $16.90 \pm 1.42$ & $3.25 \pm 0.63$ & $0.22 \pm 0.04$ & $0.03 \pm 0.04$ & $114.9 \pm 26.5$ & $452.70 \pm 10.10$ \\
\hline \multicolumn{7}{|c|}{ G r o u p IV (1.4 mg/kg ZnO NPs) } \\
\hline Liver & $28.50 \pm 1.32 *$ & $3.99 \pm 0.26$ & $0.86 \pm 0.02$ & $0.07 \pm 0.01$ & $219.0 \pm 25.0$ & $40.80 \pm 2.80$ \\
\hline Fetus & $17.90 \pm 6.46$ & $3.25 \pm 0.97$ & $0.25 \pm 0.00$ & $0.06 \pm 0.03$ & $96.5 \pm 27.6$ & $467.50 \pm 35.50$ \\
\hline \multicolumn{7}{|c|}{$\mathrm{G}$ r o u p V $(8.9 \mathrm{mg} / \mathrm{kg} \mathrm{ZnO} \mathrm{NPs})$} \\
\hline Liver & $33.90 \pm 1.71^{* *}$ & $4.93 \pm 0.12$ & $0.93 \pm 0.05$ & $0.13 \pm 0.03$ & $279.7 \pm 25.9$ & $51.10 \pm 1.96$ \\
\hline Fetus & $18.80 \pm 2.04 *$ & $3.43 \pm 0.88$ & $0.24 \pm 0.03$ & $0.04 \pm 0.02$ & $118.9 \pm 37.6$ & $456.70 \pm 12.30$ \\
\hline
\end{tabular}

Levels of micro- and macroelements in the tissues of pregnant rats and the fetus. The total amount of $\mathrm{Zn}$ in group I and group II fetuses was, respectively, by 10.80 and $5.39 \%$ lower than in the control 
group. The increases in this parameter versus control were observed: by $1.20 \%$ in group III, by $7.19 \%$ in group IV, and by $12.60 \%$ in group V. Only the maximum $\mathrm{Zn}$ concentration $(18.8 \pm 3.04 \mu \mathrm{g} / \mathrm{g})$ with $\mathrm{ZnO}$ NP administration at a dose of $8.9 \mathrm{mg} / \mathrm{kg}$ had a significant effect on the fetal accumulation of zinc in group $\mathrm{V}$ (Table 2).

Administration of $\mathrm{Zn}$ NPs and ZnO NPs was not followed by significant changes in the chemical composition of the liver in mother rats (see Table 2), but an increase in the level of essential elements in group $\mathrm{V}$ was tended.

The nature of these changes was due to a slight increase in the levels of $\mathrm{I}, \mathrm{Cu}, \mathrm{Fe}$, and $\mathrm{Se}$ in the liver of group $\mathrm{V}$ rats. The amount of essential elements in the liver of group IV rats decreased compared to control. Our results suggest a possible increase in the bioavailability of a number of essential elements with $\mathrm{Zn}$ $\mathrm{NP}$ and $\mathrm{ZnO} \mathrm{NP}$ administration.

Thus, with intraperitoneal administration of $\mathrm{Zn}$ and $\mathrm{ZnO}$ nanoparticles ( $\mathrm{Zn}$ NPs and ZnO NPs) in pregnant rats, we observed no embryo-fetal abnormalities. A significant increase in the number of red blood cells and hemoglobin concentration were demonstrated under $\mathrm{Zn}$ NP administration. Administration of $\mathrm{ZnO}$ NPs resulted in the development of mild leukocytosis. Increased enzyme activity (alanine aminotransferase, aspartate aminotransferase, and lactate dehydrogenase) in females indicates destructive processes in hepatocytes the intensity of which is directly dependent on the dose and type of nanoparticles. The study of blood chemical parameters confirm a potentially hepatotoxic effect of Zn NPs and $\mathrm{ZnO}$ NPs as evidenced by microstructural reorganization of the liver reflecting degenerative changes and cytolysis, on the one hand, and regeneration and functional activation of the organ, on the other hand, which may be considered as compensatory (adaptive) reactions to the toxic effects of nanoparticles. According to the severity of the events described and considering the comparable doses, ZnO NPs can be attributed to the most toxic ones compared to Zn NPs. Administration of $\mathrm{Zn}$ NPs and ZnO NPs did not cause critical changes in the pool of macro- and microelements and $\mathrm{Zn}$ accumulation in the liver of mother rats and fetal tissues. A slight accumulation of essential elements was observed which had no effects on the course and outcome of pregnancy, however.

\section{REFEREN C ES}

1. He rnández B a t te z A., Go nzález R., Vi es ca J.L. CuO, $\mathrm{ZrO}_{2}$ and $\mathrm{ZnO}$ nanoparticles as antiwear additive in oil lubricants. Wear, 2008, 265(3-4): 422-428.

2. Schilling K., Bradford B., Castelli D., Dufour E., Nash J.F., Pape W., Schulte S., Tooley I., van den Bosch J., Schellauf F. Human safety review of «nano» titanium dioxide and zinc oxide. Photochem. Photobiol. Sci., 2010, 9(4): 495-509 (doi: 10.1039/b9pp00180h).

3. Gerloff K., Albrecht C., B oots A.W., Förster I., Schins R.P.F. Cytotoxicity and oxidative DNA damage by nanoparticles in human intestinal Caco-2 cells. Nanotoxicology, 2009, 3(4): 355-364 (doi: 10.3109/17435390.2009.525670).

4. Jin T., Sun D., Su J.Y., Zhang H., Sue H.J. Antimicrobial efficacy of zinc oxide quantum dots against Listeria monocytogenes, Salmonella enteritidis, and Escherichia coli O157:H7. J. Food Sci., 2009, 74(1): M46-M52 (doi: 10.1111/j.1750-3841.2008.01013.x).

5. He L., Li u Y., M ustapha A., Li n M. Antifungal activity of zinc oxide nanoparticles against Botrytis cinerea and Penicillium expansum. Microbiol. Res., 2011, 166(3): 207-215 (doi: 10.1016/j.micres.2010.03.003).

6. Rasmussen J.W., Martinez E., Louka P., Wingett D.G. Zinc oxide nanoparticles for selective destruction of tumor cells and potential for drug delivery applications. Expert Opin. Drug Deliv., 2010, 7(9): 1063-1077 (doi: 10.1517/17425247.2010.502560).

7. John S., Marpu S., Li J., Omary M., Hu Z., Fujita Y., Ne ogi A. Hybrid zinc oxide nanoparticles for biophotonics. J. Nanosci. Nanotechnol., 2010, 10(3): 1707-1712.

8. D ri nke r P., Th o m s o n R.M., F in n J.L. Metal fume fever: IV. Threshold doses of zinc oxide, preventative measures, and the chronic effects of repeated exposures. J. Ind. Hyg. Toxi- 
col., 1927, 9: 331-345.

9. Blanc P., Wong H., B ernstein M.S., B oushey H.A. An experimental human model of metal fume fever. Ann. Intern. Med., 1991, 114(11): 930-936 (doi: 10.7326/0003-4819114-11-930).

10. B a e k M., C hung H.E., Y u J., L e e J.A., K i m T.H., O h J.M., L e e W.J., P a e k S.M., L e e J.K., J e o ng J., Ch o y J.H., C h o i S.J. Pharmacokinetics, tissue distribution, and excretion of zinc oxide nanoparticles. Int. J. Nanomed., 2012, 7: 3081-3097 (doi: 10.2147/IJN.S32593).

11. Vas e e m M., U ma r A., Hahn Y.B. ZnO nanoparticles: growth, properties, and applications. In: Metal oxide nanostructures and their applications. A. Umar, Y.B. Hahn (eds.). Valencia, CA, American Scientific Publishers, 2010: 1-36.

12. Y a h C.S., S i m at e G.S., I y u k e S.E. Nanoparticles toxicity and their routes of exposures. Pak. J. Pharm. Sci., 2012, 25(2): 477-491.

13. Lu X., Liu Y., Kong X., Lobie P.E., Chen C., Zhu T. Nanotoxicity: a growing need for study in the endocrine system. Small, 2013, 9(9-10): 1654-1671 (doi: 10.1002/smll.201201517).

14. I a vi coli I., Fonta n L., Le so V., B e rga mas chi A. The effects of nanomaterials as endocrine disruptors. Int. J. Mol. Sci., 2013, 14(8): 16732-16801 (doi: 10.3390/ijms140816732).

15. Yamashita K., Yos hiok a Y. Safety assessment of nanomaterials in reproductive developmental field. Yakugaku Zasshi. (Japanese), 2012, 132(3): 331-335.

16. GOST R 53434-2009. Printsipy nadlezhashchei laboratornoi praktiki. Tekhnicheskie trebovaniya [State standards GOST R 53434-2009. Principles of good laboratory practice. Technical requirements]. Moscow, 2010 (in Russ.).

17. GOST R 51000.3-1996. Obshchie trebovaniya $k$ ispytatel'nym laboratoriyam. Tekhnicheskie trebovaniya [State standards GOST R 51000.3-1996. General requirements for testing laboratories. Technical requirements]. Moscow, 1996 (in Russ.).

18. Rukovodstvo po laboratornym zhivotnym $i$ al'ternativnym modelyam $v$ biomeditsinskikh tekhnologiyakh /Pod redaktsiei N.N. Karkishchenko, S.V. Gracheva [Guidance on laboratory animals and alternative models in biomedical technology. N.N. Karkishchenko, S.V. Grachev (eds.)]. Moscow, 2010 (in Russ.).

19. S c heffé H. A method for judging all contrasts in the analysis of variance. Biometrika, 1953, 40(1/2): 87-110.

20. S i m o n o v P.V., R e z n i c he $\mathrm{nk}$ o L.S., C h e k m a n I.S. Vestnik Vitebskogo gosudarstvennogo meditsinskogo universiteta, 2015, 14(4): 112-117 (in Russ.).

21. Klinicheskaya biokhimiya /Pod redaktsiei V.A. Tkachuka [Clinical biochemistry. V.A. Tkachuk (ed.)]. Moscow, 2008 (in Russ.).

22. S h a m sut d i nova I.R., D e r k ho M.A. Izvestiya Orenburgskogo gosudarstvennogo agrarnogo universiteta, 2015, 6(56): 122-124 (in Russ.).

23. Wang L., D i ng W., Z h a ng F. Acute toxicity of ferric oxide and zinc oxide nanoparticles in rats. J. Nanosci. Nanotechnol., 2010, 10(12): 8617-8624 (doi: 10.1166/jnn.2010.2483).

24. Yan G., Huang Y., Bu Q., Lv L., D eng P., Z hou J., Wang Y., Yang Y., Li u Q., Cen X., Z h a o Y. Zinc oxide nanoparticles cause nephrotoxicity and kidney metabolism alterations in rats. J. Environ. Sci. Health A Tox. Hazard. Subst. Environ. Eng., 2012, 47(4): 577-588 (doi: 10.1080/10934529.2012.650576).

25. Surekha P., Kishore A.S., Srinivas A., Selvam G., Goparaju A., Reddy P.N., Murthy P.B. Repeated dose dermal toxicity study of nano zinc oxide with Sprague-Dawley rats. Cutan. Ocul. Toxicol., 2012, 31(1): 26-32 (doi: 10.3109/15569527.2011.595750).

26. E m a M., Houga ard K.S., K is hi mot o A., Ho nd a K. Reproductive and developmental toxicity of carbon-based nanomaterials: A literature review. Nanotoxicology, 2016, 10(4): 391-412 (doi: 10.3109/17435390.2016.1073811).

27. Tsyganova N.A., Khai rulli n R.M., Terentyuk G.S., Khlebtsov B.N., Bogat y rev V.A., Dykman L.A., Erykov S.N., Khlebtsov N.G. Penetration of pegylated gold nanoparticles through rat placental barrier. Bull. Exp. Biol. Med., 2014, 157(3): 383-385 (doi: 10.1007/s10517-014-2572-3).

28. Z hang H., Y ang D., Y ang H., Li u H. Effect on conception and offspring development in female parental rats following intratracheal instillation of nano- $\mathrm{C} / \mathrm{ZnO}$ and $\mathrm{C}-\mathrm{ZnO}$ composite nanoparticles. Wei Sheng Yan Jiu. (Chinese), 2008, 37(6): 654-656. 